\title{
New style of honeycomb structures revealed on 3D seismic data indicate widespread diagenesis offshore Great South Basin, New Zealand
}

By

${ }^{1}$ Morley, C.K., ${ }^{2}$ Maczak, A., ${ }^{1}$ Rungprom, T., ${ }^{1}$ Ghosh, J., ${ }^{2}$ Cartwright, J.A., ${ }^{2}$ Bertoni, C., and Panpichityota, N.

$1=$ Petroleum Geophysics Program,

Department of Geological Sciences,

Chiang Mai University, 50400.

Thailand,

$2=$ Department of Earth Sciences,

University of Oxford,

UK

\begin{abstract}
In the Great South Basin, within the Eocene section, at time-depths around 700-900 ms two way time below the seafloor, unusual features are observed on 3D seismic data closely associated with polygonal faults. The features, referred to as honeycomb structures (HS), cover an area of $\sim 600 \mathrm{~km}^{2}$, are packed circular, oval, to polygonal depressions 150-400 $\mathrm{m}$ across in plan view and several to 10+ $\mathrm{m}$ in amplitude. Polygonal faults rapidly die out at the Marshall Paraconformity, which is overlain by the Oligocene Penrod Formation. Hence the polygonal faults are inferred to have formed prior to the Marshall Paraconformity, and they cross-cut HS features. Consequently the top of the HS probably formed at burial depths of around 375-500 m, which is their decompacted depth below the paraconformity. The interval containing HSs is about $125 \mathrm{~m}$ vertical thick. There are several possible origins for the HS. The most probable is related to bulk contraction of the sediment volume accompanied by fluid expulsion, which suggests a diagenetic origin, in particular the opalA/CT transition. There are actually two polygonal fault systems (PFS) present in the area. The Southern Tier 1 PFS lies laterally to the HS and overlaps with it. The Northern PFS (Tier 2) lies above the HS, appears to be independent of the HS, and formed in the upper 200-300 m of the sediment column. The Tier 1 PFS probably formed by shear failure related to the same diagenetic effects that caused the HS.
\end{abstract}




\section{Introduction}

In the Great South Basin (GSB), New Zealand (Fig. 1), the post-rift, bathyal upper Eocene marl-prone interval imaged on 3D seismic data has revealed the presence of extensive polygonal fault systems with cell sizes typically in the range of 400-1000m (Figs. 2, 3). In some areas overlapping with the polygonal faults is a new type of seismically imaged feature (Figs. 4 and 5). These features are most strikingly seen on amplitude time and horizon slices. They form fields of circular, oval and polygonal shapes about 150-400 m across that are closely spaced (centre to centre distances are typically in the range of 180-400 m), cover an area in excess of $600 \mathrm{~km}^{2}$ and affect a zone tens of metres thick (Fig. 3). These features, like larger-scale density inversion or differential compaction structures described by Davies et al. (1999) and Davies and Cartwright (2007) have a 'bubble wrap' appearance in plan view (Fig. 5). However, the features described here in some particularly well imaged areas have a polygonal, commonly hexagonal planform morphology rather than exclusively circular (Fig. 4). Hence, we refer to these structures here as honeycomb systems (HS) following Maczak (2014).

Circular to polygonal features present in sediments can be caused by a wide variety of processes including: dissolution and collapse associated with karst, patterned ground (e.g. lithalsas) related to periglacial processes, biological growths in mound fields, diagnetically-triggered polygonal faults (including juvenile or sub-seismic scale polygonal faults), fluid escape features (e.g. pockmarks), soft sediment deformation by compaction/loading, and diagenetic changes such as opal A-opal CT transition and calcite/aragonite dissolution (e.g. Issac 1983; Hesse 1990; Kessler and Werner, 2003; Berndt, 2005; Gay et al., 2006; Cartwright, 2007; Judd and Hovland; 2007; Meadows and Davies, 2007; Moss et al. 2012; Howarth and Alves, 2016). This paper describes for the first time the nature of the HS features, discusses their likely origin, and relationship with adjacent, superimposed polygonal fault systems (PFS).

\section{Geological Setting}

The Great South Basin lies offshore, SW of New Zealand's South Island (Fig. 1). It formed as an intracontinental basin during Jurassic-Cretaceous and Late Cenomanian-Turonian extension associated with Gondwana breakup and separation of Australia, Antarctia and Zelandia (Beggs, 1993; Cook et al., 1999; Cox and Sutherland, 2007; Grobys et al., 2009; Uruski, 2010). The Santonian period represents the start of a prolonged period of transgression and subsidence in the GSB area, accompanied by drowning of earlier terrestrial and near-shore environments (Uruski, 2010; Fig. 6). This transgression culminated in widespread deposition of the organic-rich shales of the Waipawa Formation during the Paleocene-Eocene Thermal 
Maximum (Nicolo et al., 2007; Killops et al., 2000).

The upper part of the Late Cretaceous to top Eocene section comprises the post-rift subsidence phase, while the Oligocene and Neogene marks continued subsidence during a time that regionally in New Zealand is characterised by compression and onset of the Tonga-Kermadec subduction (Sutherland et al., 2010; Backe et al., 2012). The four sedimentary units that comprise the succession in the GSB are the Hoiho (Late Cretaceous, syn-rift), Pakaha (Late Cretaceous-Eocene post-rift, shale dominated), Rakiura (Eocene, marl-dominated), and Penrod (Oligocene-Neogene) groups (Fig. 6). For the shallow features discussed in this paper the Late Eocene is the key period. This period follows a transition from widespread deposition of organic-rich shales during the Paleocene-Eocene thermal maximum to deltaic progradation associated with a major Early Eocene lowstand (Nicolo et al., 2007, Killops et al., 2000). The Early Eocene delta progradation is seen in the SW part of the study area, and is present around location X in Figure 7. Deepwater (mesopelagic) conditions were established during the Middle-Late Eocene, and significant reworking by currents of sediments produced widely developed contourite deposits (ExxonMobil Exploration Company, 2010). The Rakiura Group is subdivided into the shale-dominated Laing Formation and the marl-dominated Tucker Cove Formation. These formations are lateral equivalents where the Tucker Cove Formation grades into the Laing Formation passing to the NW, but generally the Tucker Cove Formation overlies the Laing Formation.

The Eocene-Oligocene boundary is the regional Marshall Paraconformity (Figs. 7 and 8), which from DSDP studies is related to the onset of the Antarctic Circumpolar Current (Kennett et al., 1975; Fullthorpe et al., 1996; Lever, 2007). Above and below the Marshall Paraconformity are contourite deposits, and overlying it are drift sheets (Uruski and Ilg, 2006; Fig. 8). Today the study area lies in water depths of around 670 m. The HSs and PFZs discussed in this paper lie within the Upper Eocene section, and the Marshall Paraconformity is significant in this context since it marks a distinct upper limit to most of the polygonal faults (Figs. 3,7 and 8).

The closest well to the 3D survey is Pakaha-1, which lies $32 \mathrm{~km}$ east of the survey (Figs. 6 and 7) was drilled at a water depth of 2247' (685 m). The well was drilled in 1977 by Hunt International Petroleum (Petroleum Report Series, 1977) and the following descriptions are based on this report (Fig. 6). From the seafloor (2247') to $3358^{\prime}$ the section is assumed to be of Miocene-Quaternary age. No cuttings samples were collected but $1 \mathrm{~kg}$ of white Globigerina ooze was collected from a guide arm. The Oligocene (3358'-3658') is marked by soft, cherty foraminiferal limestone, that is occasionally chalky. Cuttings descriptions are of white limestone plus calcareous micritic claystone. A deepwater setting is interpreted in a subantarctic oceanic environment of 'considerable' water depths according to the Petroleum Report Series (1977). Probably this environment was not dissimilar to today, i.e. lower mesopelagic (i.e. $\sim 600-100 \mathrm{~m}$ ) and associated with 
post-rift subsidence. The upper Eocene (3658'-3655', 1115-1144 m) section is marly, with a more temperate oceanic environment. The main Upper Eocene section (3755'-4618', 1144.5-1407.6m) is a monotonous sequence of white to light grey glauconitic marls. They are interpreted as deposits of outer neritic to upper bathyal environments (Petroleum Report Series, 1997). Similar deposits are present in the Middle Eocene (1407.6-1675.8 m). Unfortunately, detailed descriptions of the Oligocene and Eocene section are lacking from the well reports because the sections are of no economic interest. Considerable caving into the Eocene section was reported, and no sidewall cores were taken. Hence the lithology is not known in detail. For the Liang Formation the gamma ray log is consistently around 65-70 API, this declines slightly to 55-60 API for the Tucker Cove Formation, while for the Oligocene there is a sharp decline to 30-40 API, reflecting a change from a higher clay component in the Eocene to less clay and more carbonate in the Oligocene section (Fig. 6).

\section{Seismic stratigraphy}

The study area can be divided into three broad units $(1,2,3)$ based on seismic character and well calibration. In the study area the basin fill is of Late Cretaceous-Recent age, and exhibits relatively continuous reflections in contrast with acoustic basement.

Unit 1 comprises the rifted sequence of clastic terrestrial to near-shore sediments overlain by argillaceous marine clastics. The sequences approximately correspond with the Late Cretaceous Hoiho and Kawau Formations, and the Paleocene Wickliffe Formation. A high amplitude, negative impedance contrast reflection marks the top of the sedimentary package, which corresponds with the Waipawa Shales (Palaeocene source rock) (Fig. 8). The unit exhibits low-amplitude, low continuity reflections. Wedge-shaped expansion of reflectors into major normal faults indicates syn-rift deposition.

Unit 2 covers the Waipawa Shale horizon to the Marshall Paraconformity (Fig. 8). The latter is a prominent reflection with a high negative impedance contrast. The upper part of Unit 2 is the focus of this study. Unit 2 is of Eocene age and predominantly comprises hemipelagics of the Laing Formation, with the Tucker Cove Formation comprising the upper 300 ms TWT ( 250 m) below the Marshall Paraconformity. The Laing Formation consists of marine clastics that fine upwards from shelfal sandy siltstones with subordinate limestones to silty shales. The high-amplitude, stratified reflections of the Tucker Cove Formation correspond with marl-dominated sedimentation. The lithological transition between the two formations is gradational.

The lower part of the Unit 2 comprises interfingering deltaic progradational packages and transgressive hemipelagites. The deltas prograded from NE to SW, and the delta front is seen in the SE part of the study 
area. At least two progradational cycles are present, but a large portion of the upper package was reworked by contour currents during the Middle Eocene. This timing is supported by the onlap geometries of overlying transgressive hemipelagites (marls), and the presence of extensive contourites within the overlying unit.

Overlying the deltaic sequences is a thin sedimentary sheet drape package characterized by well-defined, parallel reflections (Figs. 7 and 8). Reflections are generally high amplitude, but exhibit lateral variations suggesting some potential changes in facies. The general reflection pattern is of widespread, uniformly stratified deposits, implying low-energy, deep-marine deposition. In the NW part of the study area extensive mounded contourites are present. The shape of the deposits is characteristic of elongated mounded drifts of a detached type, associated with bends in the paths of contour currents (Faugeres et al., 1999). The sequence overlying the uppermost contourites hosts polygonal faults, and only occasionally do the faults penetrate into the contourite-influenced succession.

Unit 3 comprises Oligocene and younger sediments approximately equivalent to the Penrod Formation (Fig. 8). The Marshall Paraconformity forms the base of the unit, and marks an abrupt transition from marl-dominated sedimentation below, to one dominated by more carbonate-rich oozes. The Oligocene sediments are characterized by sub-parallel reflections of varying amplitudes. The reflections exhibit converging, diverging and mounded geometries and some chaotic sections that are characteristic of sediment drift sheets (e.g. Faugeres et al., 1999) and mass transport complexes.

\section{D seismic dataset}

The HSs and PFS discussed in this paper are imaged on the post-stack, time migrated GSB-3D survey (Fig. 2), which was acquired by Exxon Mobil during 2007-2008. The $1343 \mathrm{~km}^{2}$ 3D survey was acquired with eight $6000 \mathrm{~m}$ streamers towed at $10 \mathrm{~m}$ depth, and was later modified to seven cables towed at $12 \mathrm{~m}$ depth. Data was processed to zero-phase controlled amplitude, and has SEG normal polarity, i.e. highimpedance reflections are positive amplitudes, and are displayed as peaks, which are red in the displayed seismic sections.

The top of the zone of interest for HSC and PFZ structures lies 0.2-0.5 s TWT below the seafloor reflection, which is approximately horizontal at around $0.85 \mathrm{~s}$ TWT. The dominant frequency of the data is $\sim 50$ $\mathrm{Hz}$ in the upper $1 \mathrm{~s}$ below the seafloor, with vertical resolution estimated to be $9 \mathrm{~m}$. The average velocity in the upper $1 \mathrm{~s}$ is about $1800 \mathrm{~m} / \mathrm{s}$. For the reader it is convenient to round this value up to $2000 \mathrm{~m} / \mathrm{s}$, since then vertical time-depth values given in seconds or milliseconds two way time (TWT) can be simply read as approximate values in metres (i.e. $1 \mathrm{~s}$ TWT $=1000 \mathrm{~m}, 1 \mathrm{~ms}$ TWT $=1$ meter.

The seismic and well data used in this study was made available as a data pack by the New Zealand 
Government through New Zealand Petroleum and Minerals. In addition to the 3D seismic data the data pack contains 2D seismic and data on seven exploration wells drilled between 1976 and 1984. The most relevant wells for correlations with the 3D seismic area are Toroa-1, Pakaha-1 and Rakiua-1. The well data provide general stratigraphic information and horizon ties can be made between the 3D seismic and the wells using 2D data. However, the wells do not contribute to any detailed understanding of the sedimentology, petrology and geochemistry of the Upper Eocene interval of interest.

\section{Methodology}

Schlumberger Petrel and SMT Kingdom Suite software was used for seismic interpretation. A number of key stratigraphic horizons through the interval of interest (the Tucker Cove, Laing and Waipawa Shales formations) were correlated and mapped through the study area and tied from 2D data back to key exploration wells in the basin (particularly Pakaha-1, Toroa-1 and Rakiura-1)

The interval of interest lies between 1.1 and 2.6s two way travel time (about 0.2-0.5 s TWT below the seabed) (Figs. 3 and 4). Images of the HS were obtained by making time slices through the data, and timestructure maps. Auto-tracked horizons were made through all the extensive reflections (19 peaks and 19 troughs) in the interval of interest to determine the distribution of the HSs. Then three key time-structure maps representative of the HS were more carefully made by 2D autopicking seed horizons on either peaks or troughs on variably spaced lines (between 50 and 10 line spacing) depending upon local structural complexity, and then autotracking between the manual picks. Small unpicked remnant areas were infilled by interpolation. Attributes such as horizon amplitude, RMS amplitude, and coherency were used to image the HS.

\section{Results}

Polygonal Fault Morphology

Two sets of polygonal faults are present in the study area, these faults occur at different stratigraphic levels, overlap, but do not exactly coincide in areal extent, and exhibit different morphologies (Fig. 3). They are referred to here as Tier 1 and Tier 2 sets. The Tier 1 PFS exhibits a well developed polygonal morphology, affects an interval up to $1100 \mathrm{~ms}$ TWT thick and is much more regularly organized than Tier 2 . The large polygonal fault cells can range up to $2-3 \mathrm{~km}$ wide. The polygonal cells represent the less deformed areas between a belt of convergent conjugate faults. The belt of conjugate faults is up to 1-2.5 km wide at the upper part, and in some examples narrows to a single intersecting fault set with depth, or can die out as a low displacement zone typically $>1 \mathrm{~km}$ wide. On any single seismic line perpendicular to the strike of the conjugate faults the sets are typically composed of 6-9 faults. Displacements on the faults are typically in the 
range of 10-50 ms TWT.

The Tier 2 PFS is developed over an interval about $200 \mathrm{~ms}$ thick. Maximum throw values on the fault system are in the order of 10-15 ms, with the cells being around 300-400 m across. The cells are typically bounded on one or two sides by long curvilinear faults, and on 2-3 sides by short linear faults. The cells are more commonly four or five sided than 6 sided. The direction of the curvilinear faults is inconsistent.

Maximum displacement on faults was measured on $5 \mathrm{~km}$ long lines, the sum of the displacements divided by 5 is the average throw per kilometer. The average throw per kilometer was calculated for six lines, oriented every $60^{\circ}$ for $360^{\circ}$ of the compass, to account for the different strike directions of polygonal faults. The average results from these 6 lines are reported below as the average throw per kilometer. The displacement on the faults expressed as the average throw per kilometer for the Tier 1 PFS is around $90 \mathrm{~ms} / \mathrm{km}$, while for Tier 2 it is around $60 \mathrm{~ms} / \mathrm{km}$. Without putting too much reliance on the average numbers, it seems reasonable to argue that there is no large difference in the gross displacement distribution (and inferred bulk strain) between the two PFS.

The Northern (Tier 2) and Southern (Tier 1) PFS are interpreted to represent two distinct tiers of polygonal faults (sensu Cartwright, 2011), in that they are clearly layer bound, with albeit overlapping stratigraphic extents to their respective deformed intervals. These two tiers (Fig. 3) also interfinger laterally (Fig. 2), which is an interesting relationship that has not been described previously from other basins with well developed PFS.

\section{HS morphology}

The closely spaced, circular to polygonal-shaped HS morphology imaged on time and horizon slices of amplitudes and coherency, or on detailed time-structure maps are a striking characteristic of the shallow subsurface seismic data. These features occur around 1.4-1.6 s TWT, or about 600-800 ms TWT (approximately $600-800 \mathrm{~m}$ ) below the sea floor, and cover an area of over $600 \mathrm{~km}^{2}$. The HS extends into the southern area of polygonal faults and overlaps with them in a zone up to $9 \mathrm{~km}$ wide (Fig. 2). They also extend northward beyond the extent of the Southern PFS, and also underlie the Northern PFS.

The seismic reflections that display the HSs are characterized by regular, low amplitude, open undulations, with wavelengths of 150-300 m, and amplitudes of $>10 \mathrm{~ms}$ (i.e. $\sim 10 \mathrm{~m}$ ) (Fig. 5, 9). Hence attributes that show the orientations of surfaces (e.g. azimuth, dip maps) will image the HSs, and they clearly have relief on vertically exaggerated 3D oblique views of horizon surfaces (Figs. 4 and 10). In many, but not all, examples where these undulations are present the amplitudes tend to remain consistently peaks or troughs, but there is regular dimming and brightening of the amplitudes (Figs. 9 and 11). This dimming and brighten- 
ing gives rise to the circular features seen on amplitude, or RMS amplitude maps (Figs. 4 and 5). The largest of these features are associated with an interval comprising two peaks, and an intervening trough (Figs. 9 and 11). The trough reflection is discontinuous due to the downwards deflection of the overlying peak, and the lower peak reflection is similarly broken up by the downwards deflection of the overlying trough. This deflection occurs over an interval some $50 \mathrm{~ms}$ TWTT thick $(\sim 50 \mathrm{~m})$, and the deflections are up to about 20 ms TWTT deep ( 20 m) (Fig. 12). On vertically exaggerated seismic lines some high amplitude zones are Vshaped in cross-section (Fig. 11). However, in true depth these are gently dipping features inclined between $7^{\circ}$ and $13^{\circ}$ (Fig. 11D). In plan view, on horizon amplitude slices, these deflections can be seen as oval or polygonal in geometry and generally around 100-200m across, with the largest ones reaching $400 \mathrm{~m}$ (Figs. 4 and 5). The largest cells can be mapped out as having a pentagonal or hexagonal geometry with each side being up to $200 \mathrm{~m}$ long (Fig. 4).

The problem with interpreting all of the seismic reflections associated with the HS as geologically meaningful is that some features can be geophysical artifacts. Deconvolution and migration are responsible for enhancing vertical and horizontal resolution respectively. Any edge of a reflector can diffract the wavefront and hyperbolic events appear at diffraction points. Diffractions were collapsed by the post stack migration processing, but in places velocity variations can result in local over-migration. The over-migration effects seen in the data indicate the associated areas are lower velocity. Hence the marl layers affected by HS are inferred to have undergone some process that resulted in lateral changes in velocity. Possible causes of slower velocities include a relatively high fluid content related to higher primary or secondary porosity (including fractures), or density variations related to changes in mineralogy. Wiggle trace plots show that the inferred changes in velocity are accompanied by significant lateral changes in amplitude magnitude. Amplitude variations are also strongly related to velocity. These changes in amplitude are seen associated with areas that contain the HS, while amplitude variations in reflections outside the HS are much lower (Fig. 9).

Centre to centre measurements (taken from the centre points of each depression) of the HS in plan view have been made for three separate areas (Fig. 13). The results show positively skewed histograms (Fig. 13). The mode ranges between $165-189 \mathrm{~m}$ to $215-239 \mathrm{~m}$ intervals, while the maximum range of the data is $140-164 \mathrm{~m}$ to $415-449 \mathrm{~m}$. Interestingly, the ranges in centre-to-centre distances are similar irrespective of the variation in the diameter of the depressions: smaller depressions located on the margins of the region affected by the HS are slightly less densely packed in appearance, not because of inter-depression spacing, but because of their smaller diameter.

As indicated from the size of the cells above, the data show: 1) that the size of the cells is dominantly between 140-289 m, 2) that the cells are consistently closely packed to give the mode range between 165 - 
$239 \mathrm{~m}$ and the positive skew, 3) for individual areas the average cell size varies.

The 3D seismic data is of sufficiently high resolution that a minor growth section at the top of the polygonal fault systems can be seen. It is clear from the terminations of the polygonal faults, the location of the growth section, and the dips of reflections rotated by the faulting, that the polygonal faults were developed prior to the Marshall Paraconformity (Fig. 3). Since the polygonal faults can be observed to cut and offset the HS, they must be contemporaneous with, or older than, the PFS. Consequently the maximum depth to the top of HS appears to be well constrained to around 250-300 ms, or 250-300 m below the Marshall Paraconformity. At the time of formation, and removing the effects of compaction, the depth would have been somewhat greater (50\% compaction 375-450 m; 70\% compaction 425-510 m).

The HS occur over a stratigraphic interval that is about a maximum of $125 \mathrm{~m}$ thick. This stratigraphic interval comprises a reflection package of $\sim 19$ peaks and 19 troughs, of which 5 peaks, and 5 troughs show evidence for HS features on horizon slices, i.e $25 \%$ of the Late Eocene section (Fig. 3). There are some additional reflectors that show regular amplitude dimming and brightening patterns, and low-amplitude crenulations, but amplitude time slices through them fail to reveal the circular to polygonal planview geometries. Hence there remains the suspicion that more of the sequence has been affected by the process responsible for HS formation, but seismic resolution is insufficient to properly detect the features, or that subsequent diagenetic or compactional processes during burial have modified their structure and ability to be imaged. This suspicion is supported by horizon slices through reflections that do contain HS, where the clearly defined cells are present in one area but fade laterally to faint cells and then just a mottled pattern. On the vertical slices the crenulations and amplitude dimming and brightening continue from the well-defined HS into the mottled area.

Although the HSs occur within the same interval over most of the area, where they terminate to the west they cross-cut stratigraphy. This termination geometry involves transecting downwards (discordantly) through stratigraphy westwards over a vertical distance of about $35 \mathrm{~m}$, over a width of about $2.5 \mathrm{~km}$ (Fig. 14). The updip (proximal with respect to the shelf margin) termination of the HS occurs within $2 \mathrm{~km}$ of where the stratigraphy is affected by prograding clinoform geometries (Fig. 3).

\section{Discussion}

Two key questions that arise from the observation of the unusual honeycomb or 'bubble wrap' morphology seen on the GSB 3D seismic data are: what is the origin of the planform morphology and did it develop independently of the PFS or are the two related? These two questions are discussed in this section. 
The HS planform is unlike any previously described seismic facies of a truly depositional origin. The uniformity of the pattern, and its localized distribution led us to instead consider post-depositional phenomena for potential explanations for the planform. From a review of published examples with a crudely comparable morphology, we highlighted four possible explanations: 1) that the depressions are fluid escape features, 2) that the HSs represents juvenile or sub-seismic scale polygonal fault systems, 3) karst morphology, and 4) that the gross morphology is a response to soft-sediment deformation induced by diagenesis. It should be noted that the HS are close to seismic resolution, hence inferences about their origin and geometry are restricted by this limitation. It also means that counter-arguments to any proposed origin can also be made on the basis of resolution. We acknowledge therefore that this discussion is preliminary, and detailed lithological calibration is a pre-requisite for a more rigorous test of these suggestions.

The presence of numerous circular to oval features might most obviously suggest that the HS represent fluid escape pockmarks, since the planform is reminiscent of pockmark fields seen elsewhere (e.g. Moss et al. 2012) and the cross-sectional morphology could be interpreted (within resolution limits) as being craterlike (Fig. 10). Fluid escape features can, in general, have a variety of origins and geometries (e.g. Judd and Hovland, 2007), and can range from the seismic (typically vertical fluid escape pipes often terminating at the seabed as pockmarks; Cartwright et al. 2007) to sub-seismic scale (e.g. dish structures, sand volcanoes and spring pits; Judd and Hovland, 2007). Some relatively small-scale features such as spring pits can be composed of closely spaced water escape pipes, however, in general pockmarks do not occur as regular densely packed features over a large area, and are more typically clustered, and organized spatially according to the dominant heterogeneities in the immediately underlying stratigraphy (e.g. Gay et al. 2006; Pilcher and Argent, 2007; Moss et al. 2012). The HS cover an area that is greater than $600 \mathrm{~km}^{2}$. If they were indeed pockmarks resulting from highly focused fluid escape, then it is surprising that no feeders can be observed in the units beneath the HS (c.f. Loseth et al. 2012; Fig. 12). Furthermore, if the HS is an expression of fluid escape, it is not immediately evident why this specific area of around $600 \mathrm{~km}^{2}$ was such a focus for fluid venting at the seabed at this time (Eocene).

Nevertheless, we suggest that there could be two main ways to explain such a regionally restricted, yet focused fluid expulsion process: 1) fluids became focused over a large area due to a well developed top seal, and widespread, rapid loss of that top seal led to fluid expulsion. For example in the shallow subsurface the rapid dissociation of a gas hydrate layer due to either climate change or a slumping/erosional event could explain the loss of a shallow seal. 2) A widespread fluid generation and expulsion event due to diagenesis. While fluid escape maybe part of the story, the polygonal map view morphology of some areas of the HS 
would not be expected for pockmark craters, which are typically circular or oval in plan view.

The polygonal geometry juxtaposed with PFS raises the possibility that the HSs are a smaller-scale version of the polygonal faults. However, the smallest polygonal fault cells in the GSB data set are 200-400 m across, which is the same size as the largest HS cells, and the planform of the PFS in this area contrasts considerably with that exhibited by the HS. Faults can clearly be seen forming the small polygonal fault cells, while they are entirely absent in the HS cells. Additionally the polygonal faults tend to dip around $45^{\circ}-60^{\circ}$, while the boundaries of the $\mathrm{V}$-shaped cells exhibit much lower dips $\left(7^{\circ}-13^{\circ}\right)$. Consequently it seems very unlikely that the HS cells are smaller versions of the PFS.

Howarth and Alves (2016) describe karst from seismic data over the NW Browse Basin, offshore NW Australia. The karst is manifested on variance maps as closely spaced round to polygonal features 10's to 100 's m across, that at least superficially resemble the HS structures described here. Reticulate or "honeycomb" patterns in shallow marine carbonates can develop above an existing karst surface, or reticulate reefs can develop in response to spatial self-organization of scattered corals and algae, or above reticulate hydrodynamic bedforms (Schlager and Purkis, 2015). The existence of reticulate patterns in carbonates with forms that are 100's m across suggests a possible explanation for the honeycomb patterns in the Great South Basin, however, some key differences with the HS described here are: 1) the reticulate karst is generally of smaller diameter than HS, 2) in map view the geometry of the karst features is more variable, and some examples have a more irregular outline, than the circular to honeycomb shape regularly displayed by the HS features, 3) the karst features clearly lie within a carbonate platform sequence, with an exposure surface at the top. As described in the Geological Setting section the deposits in which the HS are found are deeper water marls, that do not show evidence for surface exposure. Alves (2016) discusses the development of Upper Permian carbonate mounds in the Barents sea that exhibit polygonal forms. These mounds developed in a quiet, relatively deep water setting, which suggests there maybe parallels with the HS structures. The carbonate mounds depicted in Alves (2016) appears in a unit $~ 150 \mathrm{~m}$ thick as undulations affecting continuous reflections, with relief up to about $50 \mathrm{~ms}$ TWT and an average wavelength of $\sim 250 \mathrm{~m}$. In time-slices the morphology of the mounds compared with HS structures is more irregular, often elongate to elliptical, and less regularly packed. The carbonate mounds in vertical seismic section do not exhibit the diversity of structures (e.g. the disrupted reflections, and horizon-transgressive nature, Fig. 9), and lateral dimming and brightening of amplitudes seen in honeycomb structures described here.

Regional scale $\left(>10^{4} \mathrm{~km}^{2}\right)$ diagenetic patterns have been widely reported as being associated with opal A-opal CT reaction boundaries (Davies and Cartwright 2002, 2007, Davies et al. 2006, Ireland et al. 2010, Neagu et al., 2010). These boundaries are formed during shallow burial as a result of dissolution-precip- 
itation reactions (Issac et al. 1983; Hesse 1990;). The dissolution process enhances the permeability of the host rock at a local scale yielding focused fluid transport into the system, giving rise to thermal and chemical dis-equilibrium conditions within the host rock resulting in a second stage of dissolution (Davies and Cartwright, 2007).

One of the most characteristic features of the HS as observed in the study area is the hexagonal tessellation pattern of densely packed 'cells'. The narrow linear features forming the tessellation grid correspond to ridge like features on the seismic profiles, whereas the 'cells' correspond to depressions with a concave upward geometry (Figs. 9-12). This pattern is strikingly similar to that described by Davies and Cartwright (2007) from a 3D survey in the Vøring and Møre basins. The horizon described in Davies and Cartwright (2007) is a diagenetic boundary, separating two phases of opaline (biogenic) silica, Opal A and Opal C/T. Because of the marked density contrast between sediments containing these two forms, the diagenetic boundary has a strong seismic expression, as a discrete marker reflection. Davies and Cartwright (2007) showed that the reaction boundary had an irregular morphology, and that this took the form of a ridge-trough structure with a hexagonal to sub-circular cellular planform. However, Davies (2005) also showed that depressions in the reaction boundary should be overlain by mounds in the overlying sediments, due to differential compaction, and this geometry is not apparent in our examples, which is a potential problem for any diagenetic explanation involving opaline silica transformation. More positively, the discordant geometry described from the HS near the updip limit within the study area is also a characteristic of the Opal A to Opal C/T boundary, which typically cross-cuts the stratigraphic layering of the unit hosting the diagenetic reaction boundary (Davies and Cartwright, 2002).

The cross-cutting geometry of the HS is somewhat problematic to understand because when the horizon is flatted on the Marshall Paraconformity the seafloor was approximately flat. Consequently at the inferred time of formation the HS cross-cutting geometry actually cuts down section to the west. This could be indicative of the onset of adverse conditions (e.g. chemical composition) in the upper part of the section for HSs formation, and/or lateral changes in geothermal gradient. Silica diagenesis is well known to be affected by host sediment composition (Kastner et al. 1977). In siliceous mudstones and marls a key diagenetic effect occurs when biogenic silica deposited as amorphous opal-A interacts with aqueous solutions to transform into microcrystalline opal-CT (cristobalite/tridymite), chalcedony, and eventually to quartz (e.g. Isaacs et al. 1983; Hesse, 1990) with increasing burial and temperature. These changes in mineralogy are accompanied by changes in rock properties such as porosity, permeability, acoustic response, and are marked by a change in bulk rock volume. The chemistry and ionic strength of the fluid phase influences the dissolution rates and solubilities of the silica phases (Hesse, 1990). The presence of calcium carbonate increases alkalinity, which 
favours precipitation of opal-CT at relatively shallow depths (Otsuka, 1983). DSDP results have found the occurrence of opal-CT in Miocene and Palaeogene sediments at depths of about 300-400 m below the seafloor (Otsuka, 1983; Henrich, 1989). While ODP Leg 127/128 site 795 documented a 20\% decrease in porosity around $330 \mathrm{~m}$ depth associated with the opal-A to opal-CT transition (Meadows and Davies, 2008). Other diagenetic mechanisms may also be complimenting the opal-A to opal-CT transition, such as authigenic carbonate diagenesis and the transition from immature to mature opal-A (e.g. Pisciotto, 1981; Isaacs et al., 1983; Henrich, 1989).

If the HS structures are related to the opal-A/CT transition then an explanation should be sought for the contrast in the dimensions of the cellular structure between this example and those described from a number of other basins. Ireland et al. (2010), Davies, (2005) and Davies and Cartwright, (2007) describe approximately circular morphologies associated with the OpalA/Ct diagenetic boundary reactions from various basins where the diameters of the depressions range from 1-2 km, and the depressions are spaced 1-3 km apart. The diagenetic fronts are formed on top of the polygonal fault zones, and the boundaries of the circular depressions roughly aligned with the polygonal faults underlying these structures. This observation implies that these structures are related in their origin. In this study, however, the polygonal faults cross cut the HSs containing horizons along the distal side, whereas towards the proximal side the faults are restricted to an interval that is clearly above the HS horizon (Figs. 2 and 3).

\section{Relationship of HS to PFS}

From the discussion above the evidence leans strongly, if not definitively, towards a diagenetic origin for the HS. There is also strong evidence to suggest that diagenetically induced shear failure is the mechanism for polygonal fault development, with the opal-A to opal-CT transition being a particularly important contributor (Shin et al., 2008; Cartwright, 2011). Hence it is necessary to consider if any relationship can be seen between the HS and the PFS in the Great South Basin 3D seismic data.

The relatively long vertical extent faults forming the Tier 1 PFS in places exhibit evidence for vertical linkage of two initially separate faults. Displacement maxima can be found on the faults at time-depths of about 1.4-1.5 s TWT and 1.8-2.1 s TWT. In the Tier 1 PFS the top of the HS horizon 1.6-1.75 s TWT. Hence the lower displacement maxima of the polygonal faults lies within, or laterally equivalent to, the zone affected by HS (Fig. 3). The Tier 2 PFS, and the upper part of the Tier 1 PFS overlie the zone affected by HSs (Fig. 3). It is clearly the case for the Tier 2 PFS that the faults die out downwards towards the top of the HS, and hence do not appear to be related. It is possible to argue that the bulk contraction caused by diagen- 
esis associated with the HS interval is manifest as different structures in different places, perhaps related to the intensity of the process or lateral variations in the nature of the process related to the sediment or pore fluid composition. Consequently the HS might represent one response, and the polygonal faults a different response to bulk contraction of the layer, with the two phenomena overlapping in a zone up to $9 \mathrm{~km}$ wide.

The upper part of Tier 1 and Tier 2 PFS present a significant problem in the model advocated above. It has been argued here that the timing of polygonal fault formation is clearly prior to the Marshall Paraconformity. Formation of polygonal faults above the HS but below the Marshall Paraconformity means that the faults must have nucleated in the upper 100-200 m of section below the seafloor. From the evidence discussed here this indicates they formed above the opal-A/CT transition. Hence if a diagenetic origin is attributed to these faults following Cartwright (2011), it must be due to a cause other than the opal-A/CT transition. Perhaps in this context the difference in geometries between tiers 1 and 2 PFS reflects that different diagenetic processes drove the two systems.

Tewksbury et al. (2014) described extensive rock pavement outcrops that contain polygonal faults in chalk of the Cretaceous Khoman Formation, from the Western Desert of Egypt. Associated with the polygonal faults are small synformal depressions. The depressions are interpreted by Tewksbury et al. (2014) as fluid escape features related to polygonal faults, where the faults grew through the earlier formed depressions. The circular depressions are about $200 \mathrm{~m}$ across. Due to the absence of clay and biogenic silica within the formation Tewksbury et al. (2014) concluded that diagenesis related to volume change associated with biogenic silica or smectite is not a viable mechanism to explain the polygonal faults and that pore fluid pressure related to compaction and burial played an important role in polygonal fault initiation and development. In a study of chalks from the Goban Spur, Jennings and Mazzullo (1985) observed that chalk undergoes near-exclusive mechanical compaction at shallow burial depths $(100-300 \mathrm{~m})$, but between burial depths of 300-400 m both mechanical and chemical compaction features can be present in chalk, while between 400 and $570 \mathrm{~m}$ chemical compaction dominates. These authors noted that chemical compaction actually dominates shallow loss of porosity. Consequently Tewksbury et al. (2014) may have inferred incorrectly that the polygonal faults are not related to diagenesis, although the mechanisms of diagenesis would have been different from those of clastic mudrocks.

The morphology of the circular basins described by Tewksbury et al. (2014), i.e. small circular basins 50-200 $\mathrm{m}$ in diameter, spaced $200-500 \mathrm{~m}$ apart, with inward dips between $5^{\circ}$ and $20^{\circ}$ is similar to that observed for the HS in the GSB. The basins contain radial vertical veins of calcite and goethite. Tewksbury et al. (2014) suggested there was a strong genetic relationship between overpressure, development of the circular basins, and development of polygonal faults. This is similar to our findings here too, except we can 
demonstrate that the HS do not always coincide with the polygonal faults, and we infer that diagenesis has a significant role to play in their development. One indicator that the circular basins and the HS are of different origins is the circular nature of the Egypt examples, versus the more honeycomb morphology of the GSB examples. But since the GSB examples actually range from being circular to polygonal in morphology, this difference may not be too significant.

Davis et al. (2006) and Davis and Cartwright (2007) have shown that silica diagenesis can have a basin wide extent, is associated with significant volume change reactions in the upper $1 \mathrm{~km}$ of sedimentary section, and the volume change, and processes associated with propagating the reaction boundary can give rise to a variety of features at the sub-seismic and the seismic scale. These features include clastic intrusions primed by overpressured fluids released during conversion of opal A to opal CT (Davies et al., 2006), and vertical growth-dominated reaction boundary patterns, with a polygonal map view pattern ( 1 km across), strongly influenced by pre-existing polygonal faults. Since the reaction boundary features can range from seismic to sub-seismic scale, and are influenced by the local factors, such as polygonal fault patterns and sediment geochemistry there is no reason why silica diagenesis should produce similar reaction boundary patterns and dimensions in all basins. We propose that HSs are another variation in the way volume change and release of fluids associated with silica diagenesis is manifest in basins. We reviewed carbonate processes that give rise to polygonal features and concluded that there was not a good match with the HSs described here, but the HSs also differ in morphology from previously described examples of silica diagenetic structures. Consequently it would be premature to rule out the possibility that a combination of processes operated, related to carbonate diagenesis, polygonal faults, and silica diagenesis. However drilling and detailed sampling (preferably coring) and analysis of the Tucker Cove Formation is required to further advance our understanding of the origin of the HSs.

\section{Conclusions}

The HS are a previously undescribed feature of the shallow subsurface formed in fine-grained, deepwater sediments. The characteristic morphology is seen as packed circular, oval, to polygonal depressions 150-400 $\mathrm{m}$ across in plan view, several to $10+\mathrm{m}$ in amplitude, that cover an area in excess of $600 \mathrm{~km}^{2}$. The top of the HS probably formed at burial depths of around 375-450 m (50\% decompaction). The zone of HS extends up to about $125 \mathrm{~m}$ vertical thickness. Although there are several possible origins for the HS, the most probable origin is that bulk contraction of the sediment volume accompanied by fluid expulsion caused the structures, which suggests a diagenetic origin. In particular the opal-A/CT transition is inferred to be the most likely 
cause, although possibly multiple factors combined to form the HS.

Two polygonal fault systems are present in the area. Tier 1 PFS lies laterally to the HS and overlaps with them, the other (Northern PFS) lies above. The Northern PFS appears to be independent of the HSs, and formed in the upper 200-300 m of the sediment column. The Southern PFS may well have formed by shear failure as a consequence of the same diagenetic effects that caused the HS, and both features are different, overlapping manifestations of the same process.

\section{Acknowledgements}

We would like to thank New Zealand Petroleum \& Minerals for providing the exploration data pack over the study area. Schlumberger Petrel and SMT Kingdom Suite software are thanked for providing academic licenses to interpret the seismic data. We would like to thank Stefan Back and Tiago Alves for reviews that considerably helped to improve the manuscript

\section{REFERENCES}

Alves, T. M., 2016. Polygonal mounds in the Barents Sea reveal sustained organic productivity towards the P-T boundary. Terra Nova, 28, 50-59.

Bache, F., Sutherland, R., Stagpoole, V., Herzer, R., Collot, J. and Rouillard, P., 2012. Stratigraphy of the southern Norfolk Ridge and the Reinga Basin: A record of initiation of Tonga Kermadec Northland subduction in the southwest Pacific. Earth and Planetary Science Letters, 321-322, 41-53, 2.

Beggs, J.M., 1993. Depositional and tectonic history of the Great South Basin. In: Balance, P.F. (ed.), South Pacific sedimentary basins. Sedimentary basins of the world 2, Elsevier Science, Amsterdam, 365-373. Berndt, C. 2005. Focused fluid flow in passive continental margins. Phil. Trans. R. Soc. A (2005) 363, 2855-2871 doi:10.1098/rsta.2005.1666

Carter, R. M., 1985. The Mid-Oligocene Marshall Paraconformity, New Zealand: Coincidence with Global Eustatic Sea-Level Fall or Rise? The Journal of Geology,93, 359-371.

Cartwright, J.A. 2007. Bicentennial Review: The impact of 3D seismic data on the understanding of compaction, fluid flow and diagenesis in sedimentary basins. Journal of the Geological Society of London, 164 (5), 881-893. doi: 10.1144/0016-76492006-143

Cartwright, J.A., Huuse, M., and Aplin, A. 2007. Topseal bypass systems. AAPG Bulletin, 91, 1141-1166. 
Cartwright J., 2011. Diagenetically induced shear failure of fine-grained sediments and the development of polygonal fault systems. Marine and Petroleum Geology, 28, 1593-1610.

Cook, R.A., Sutherland, R., Zhu, H., 1999. Cretaceous-Cenozoic geology and petroleum systems of the Great South Basin, New Zealand. Institute of Geological and Nuclear Sciences Monograph, 20, Lower Hutt, New Zealand, 188p.

Cox, S.C. and Sutherland, R., 2007. Regional geological framework of South Island, New Zealand, and its significance for understanding the active plate boundary. In: Okaya, F.D.D., and Stern, T. (eds.), Geophysical Monograph Series, American Geophysical Union, Washington D.C., 19-46.

Davies,R.J. 2005. Differential compaction in sedimentary basins due to silicadiagenesis: a case study.Geological Society of America Buletin, 117,1146-1155.

Davies, R. J. and Cartwright, J., 2007. Kilometer-scale chemical reaction boundary patterns and deformation in sedimentary rocks. Earth and Planetary Science Letters 262, 125-137

Davies, R.J., and Cartwright, J., 2002. A fossilized Opal A to Opal C/T transformation on the northeast Atlantic margin: support for a significantly elevated Palaeogeothermal gradient during the Neogene? Basin Research, 14, 467-486.

Davies, R. J., Ireland, M.T. and Cartwright, J., 2009. Differential compaction due to the irregular topography of a diagenetic reaction boundary: a new mechanism for the formation of polygonal faults. Basin Research, 21, 354-359.

Davies, R. J., Huuse, M., Hirst, P.,Cartwright, J., and Yang Y., 2006. Giant clastic intrusions primed by silica diagenesis. Geology, 34, 917-920

ExxonMobil Exploration Company, 2010. New Zealand Unpublished Petroleum Report PR4233, Technical Report, Ministry of Development, 2.

Faugeres, J.-C., Stow, D.A.V., Imbert, P., and Viana, A., 1999. Seismic features diagnostic of contourite drifts. Marine Geology, 162, 1-38. Ford, D. and Williams, P., 2007. Karst Hydrogeology and Geomorphology. John Wiley \& Sons Ltd., Chichester, 562 pp.

Fulthorpe, C.S., Carter, R.M., Miller, K.G. and Wilson, J., 1996. Marshall Paraconformity: a mid-Oligocene record of inception of the Antarctic circumpolar current and coeval glacio-eustatic lowstand?, Marine and Petroleum Geology, 13, 61-77.

Gay, A., Lopez, M., Cochonat, P., Seranne, M., Levache, D. and Sermondadaz, G., 2006. Isolated seafloor pockmarks linked to BSRs, fluid chimneys, polygonal faults and stacked Oligocene-Miocene turbiditic palaeochannels in the Lower Congo Basin. Marine Geology, 226, 25-40. 
Grobys, J., Gohl, K., Uenselmann-Neben, G., Davy, B., and Barker, D., 2009. Extensional and magmatic nature of the Campbell Plateau and Great South basin from deep crustal studies. Tectonophysics, 472, 213-225.

Hesse, R., 1990. Origin of Chert: Diagenesis of biogenic silicious sediments. In: McIlreath, I.A., Morrow, D.W. (eds.), Diagenesis, Geoscience Canada Reprint Series, 4, 227-252.

Henrich, R. 1989. 7. Diagenetic environments of authigenic carbonates and opal-CT crystallization in Lower Miocene to Upper Oligocene deposits of the Norwegian Sea (ODP Site 643, Leg 104). In: Eldholm, O., Thiede, J., and Taylor, E. (eds.), Proceedings of the Ocean Drilling Program, Scientific Results, 104, 233-247.

Howarth, V. and Alves, T.M., 2016. Fluid flow through carbonate platforms as evidence for deep-seated reservoirs in Northwest Australia. Marine Geology, 380, 17-43.

Ireland, M. T., Goulty, N. R. and Davies, R. J., 2010. Influence of pore water chemistry on silica diagenesis: evidence from the interaction of diagenetic reaction zones with polygonal fault systems Journal of the Geological Society,167, 273-279. doi: 10.1144/0016-76492009-049.

Isaacs, C. M., Pisciotto, K.A. and Garrison, R.E., 1983. Facies and diagenesis of the Miocene Monterey Formation, California: a summary. In: Iijima, A., Hein, J.R. and Siever, R. (eds.), Siliceous deposits in the Pacific Region. Developments in Sedimentology, 36, Elsevier, Amsterdam, 247-282.

Jagla, E.A. and Rojo, A.G., 2002. Sequential fragmentation: the origin of columnar quasihexagonal patterns. Physical Review E65, 026203, http://dx.doi.org/10.1103/PhysRevE.65.026203

Jennings, R. H. and Mazzullo, J. M., 1985. Shallow burial diagenesis of chalks and related sediments at Site 550 on the Goban Spur. In: De Graciansky, P.C., Poag, C.W. (eds.), Intial Reports of the Deep Sea Drilling Project, Washington, 80, 853-861.

Judd, A., and Hovland, M., 2007, Seabed fluid flow: the impact on geology, biology and the marine environment, Cambridge University Press.

Kastner, M., Keene, J.B. \& Gieskes, J.M. 1977. Diagenesis of siliceous oozes- I. Chemical controls on the rate of opal-A to opal-CT transformation- an experimental study. Geochimica et Cosmochimica Acta, 41, 1041-1051.

Kennett J.P., Houtz, R.E., Andrews, P.B., Edwards, A.R., Edwards, A.R., Gostin, V.A., Hajos, M., Hampton, D.G., Jenkins, S.G., Margolis, S.V., Ovenshine, A.T., and Perchnielsen, K., 1975. Cenozoic paleocean- 
ography in the southwest Pacific Ocean, Antarctic Galciation, and the development of the CircumAntarctic Current. Technical Report, Initial Reports of the Deep Sea Drilling Project, 2.

Kessler, M.A. and Werner, B.T., 2003. Self-organization of storted patterned ground. Science, 299, 380-383. Killops S., Hollis, C., Morgans, H., Sutherland, R., Field, B. and Leckie, D., 2000. Paleoceanographic significance of Late Paleocene dysaerobia at the shelf/slope break around New Zealand. Palaeoceanography, Palaeoclimatology, Palaeocology, 156, 51-70

Lever, H., 2007. Review of unconformities in the late Eocene to early Miocene successions of the South Island, New Zealand: Ages, correlations and causes. New Zealand Journal of Geology and Geophysics, 50, 245-261.

Loseth, H., Rodrigues, N. and Cobbold, P.R., 2012. World's largest extrusive body of sand? Geology, 40, 467-470.

Maczak, A., 2014. Insights into soft-sediment deformation of the Great South Basin, New Zealand. Unpublished MEarthSci degree thesis, University of Oxford, 89pp.

Meadows, D. and Davies, R.J., 2008. Predicting porosity reduction due to silica diagenesis using seismic reflection data. Marine and Petroleum Geology, 26,

Meadows, D. \& Davies, R.J. 2007. Morphological development of basin-scale silica diagenetic fronts revealed with 2D seismic reflection data: offshore Sakhalin, Russian Far East. Journal of the Geological Society, London, 164, xxxx-Xxxx.

Moss, J.L. and Cartwright, J., 2010. 3D seismic expression of km-scale fluid escape pipes from offshore Namibia. Basin Research, 22, 481-501.

Moss, J., Cartwright, J.A., Cartwright, A. and Moore, R. 2012. The spatial pattern and drainage cell characteristics of a pockmark field, Nile Deep Sea Fan. Marine and Petroleum Geology, 35, 321-356. doi: $.1016 /$ j.marpetgeo.2012.02.019

Neagu, R. C., Cartwright, J.A., and Davies, R., 2010. Measurement of diagenetic compaction strain from quantitative analysis of fault dip slip. Journal of Structural Geology, 32, 641-655.

Nicolo, M.J., Dickens, G.R., Hollis, C.J. and Zachos, J.C., 2007. Multiple early Eocene hyperthermals: Their sedimentary expression on the New Zealand continental margin and in the deep sea. Geology, 35, 699702

Pisciotto, K.A., 1981. Diagenetic trends in the siliceous facies of the Monterey Shale in the Santa Maria Region, California. Sedimentology, 28, 547-571. 
Schlager, W. and Purkis, S., 2015. Reticulate reef patterns - antecedent karst versus self-organization. Sedimentology, 62, 501-515.

Shin, H.J., Santamarina, J.C. and Cartwright, J.A., 2008. Contraction-driven shear failure in compacting uncemented sediments. Geology, 36, 931-936

Sutherland, R., Collot, J., Lafoy, G., Logan G.A., Hackney, R., Stagpoole, V., Uruski, T., Hashimoto, T., Higgins, K., Herzer, R. H., Wood, R., Mortimer, N. and Rollet, N., 2010. Lithosphere delamination with foundering of lower crust and mantle caused permanent subsidence of New Caledonia Trough and transient uplift of Lord Howe Rise during Eocene and Oligocene initiation of Tonga-

Otsuka, K., 1983, 52. Silicified sediments and silica diagenesis in the Goban Spur area of the Northeast Atlantic, Leg 80. Deep Sea Drilling Project Initial Reports volume 80, 1081-1099.

Petroleum Report Series, 1977. Pakaha-1 well completion report. Ministry of Economic Development, PR 703, 290pp.

Pilcher, R. and Argent, J., 2007. Mega-pockmarks and linear pockmark trains on the West African continental margin. Marine Geology, 244, 15-32.

Tewksbury, B.J., Hogan, J.P., Kattenhorn, S.A., Mehtens, C.J., and Tarabees, E.A., 2014. Polygonal faults in chalk: Insights from extensive exposures of the Khoman Formation, Western Desert, Egypt. Geology, $42,479-482$.

Uruski, C. and Ilg, B., 2006. Preliminary Interpretations and Structural Modelling of DUN06 Seismic Reflection Data from Great South Basin, Offshore New Zealand. Technical Report, Crown Minerals. Uruski, C. I., 2010. New Zealands deepwater frontier. Marine and Petroleum Geology, 27, 2005-2026.

\section{FIGURES}

Figure 1 Location map for the study area in the Great South Basin, New Zealand.

Figure 2 Regional map of the study area, showing the 3D survey area, where honeycomb (HSs) structures occur within the survey and the distribution of polygonal faults. The grey-scale image is a similarity time slice at $1.5 \mathrm{~s}$ two way time, which shows extensive polygonal fault development. See Fig. 1 for location.

Figure 3. Regional inline showing the relationship between zones of HSs and polygonal faults. See Fig. 2 for location

Figure 4. Subset of the 3D seismic volume illustrating key features related to the occurrence of the honey- 
comb structures (HSs). Inset shows detail of the honeycomb structure morphology. See Fig. 2 for location. Figure 5. Amplitude time slice at $1456 \mathrm{~ms}$ through the Great South Basin 3D seismic data set, with a zoom in to show the detailed structure around line XL3699.

Figure 6. Stratigraphic column for the Great South Basin, and extract of well log-seismic tie over the Eocene and Oligocene interval for the Parihaka-1 well.

Figure 7. Composite seismic line showing the passage from the continental slope. The seismic section is composed of a regional 2D seismic line and a section through the 3D seismic survey. The lateral limit of the Tier 1 precedes the appearance of extensive, mounded contourite deposits located within the more proximal part of the fault-hosting sequence.

Figure 8. Composite seismic section showing the Pakaha-1 well tie with the study area. A summary of the well data (ages, lithologies, depositional environments) is shown on the right side panel. There is a good correlation of horizons and depositional environments with the Pakaha-1 well and the study area. Note the same zones of polygonal faults present in the Pakaha-1 well in the Tucker Cove and Liang Formations extends into the study area, suggesting the same fine-grained facies is present in the study area. Yellow horizon = Marshall Paraconformity.

Figure 9 Expression on HSs on seismic sections, with wiggle display showing amplitude variations across the features.

Figure 10. Expression of HSs on an oblique view of a horizon, showing the topography related to HSs and polygonal faults. B, C and D are sub-sets of A. See Figure 2 for location, and Figure 3 for location of horizon on a vertical section.

Figure 11. Examples of HSs on vertical seismic lines. See Fig. 2 for locations. A) The 'flat-with-wings' profile geometry is characteristic of hexagonal cells in map view. B) 'Bowl-shaped' geometry is associated with smaller, more rounded cells. C) 'V-shaped' profile geometry indicates a possibility of the involvement of small-scale faulting in the formation of HSs. D) Bowl-shaped profile at vertical=horizontal scale. No seismically-resolvable deformation of the overlying and underlying intervals accompanies the HSs.

Figure 12.3D oblique views of HSs on 4 mapped horizons from 3D seismic data. The mapping illustrates that commonly depressions on one horizon line up vertically with depressions on other horizons suggesting the presence of short, connected pipe-like features. 
Figure 13. Histogram showing the frequency of occurrence of distances between the centre points of adjacent honeycomb structures for three different areas in the data set.

Figure 14. Arbitrary 3D seismic section showing the plunging top to honeycomb structures (HSs) on the NW margin of the HSs field. The cross-cutting relationship of the top with respect to stratigraphy marks a $35 \mathrm{~m}$ ramp down to the NW in the top of the HSs features over a distance of $2.5 \mathrm{~km}$. 


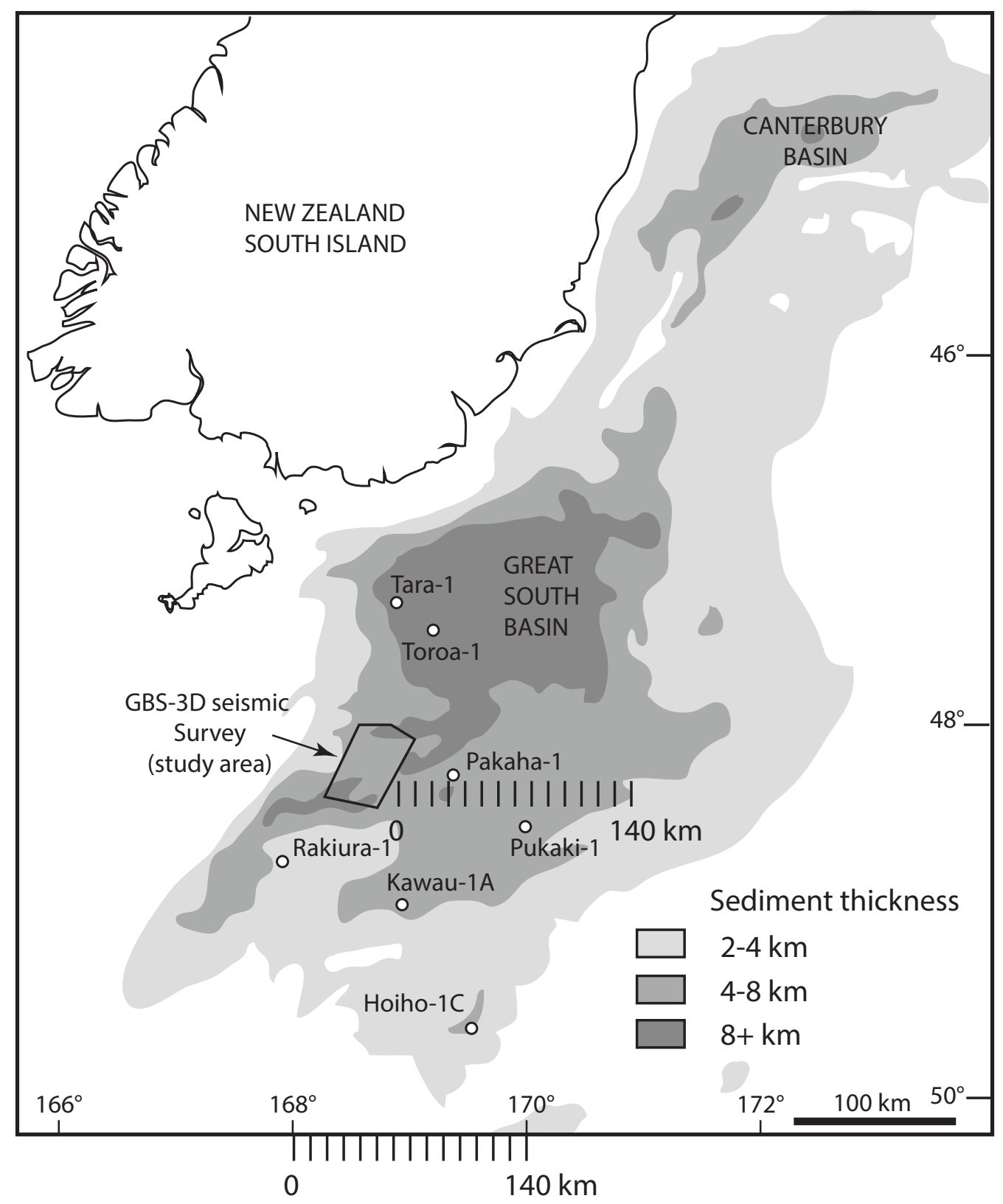

Figure 1 


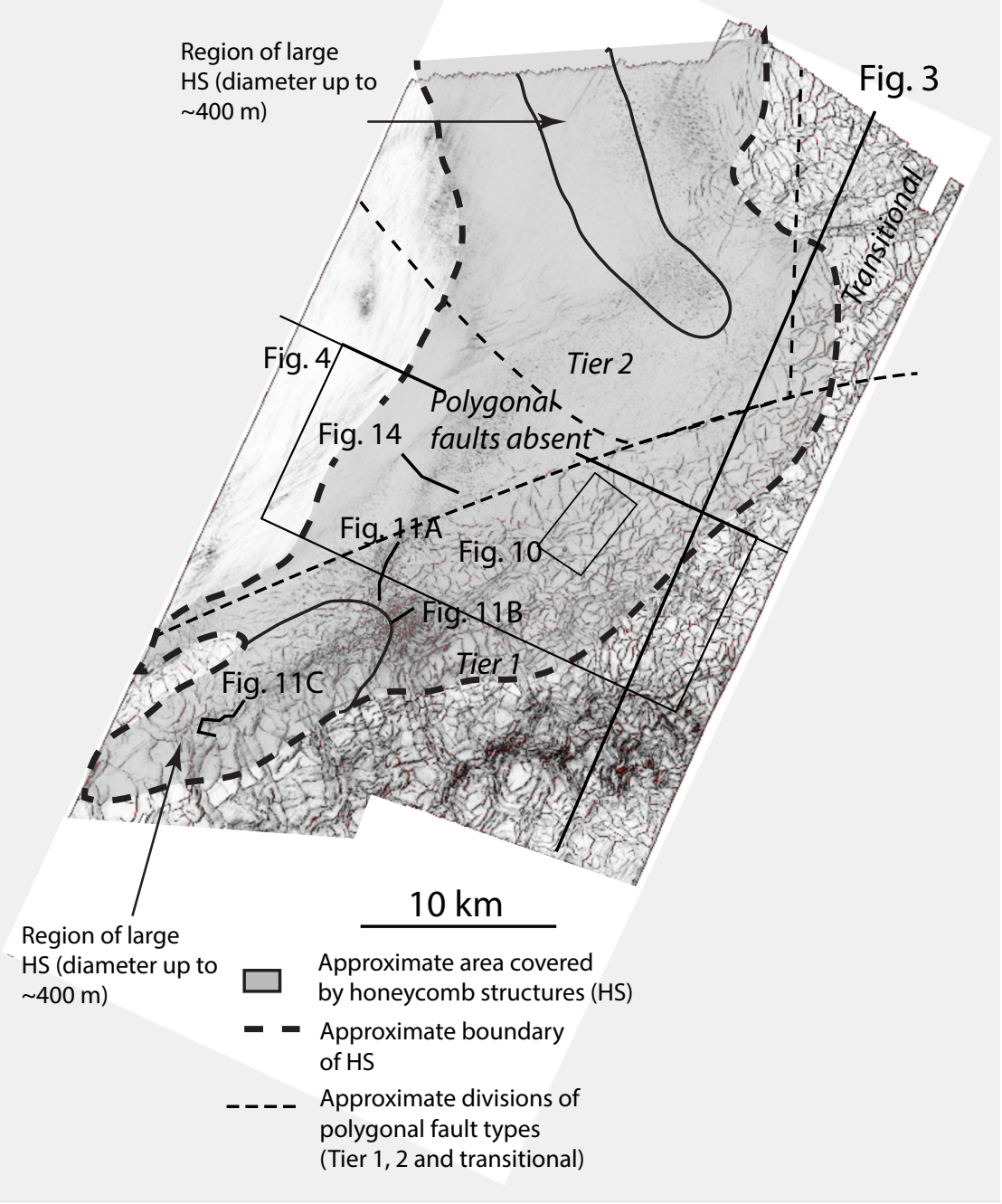

Figure 2 



Zone of closely spaced pockmarks

Approximate zone of diagenetic reaction driving polygonal faults

Figure 3 


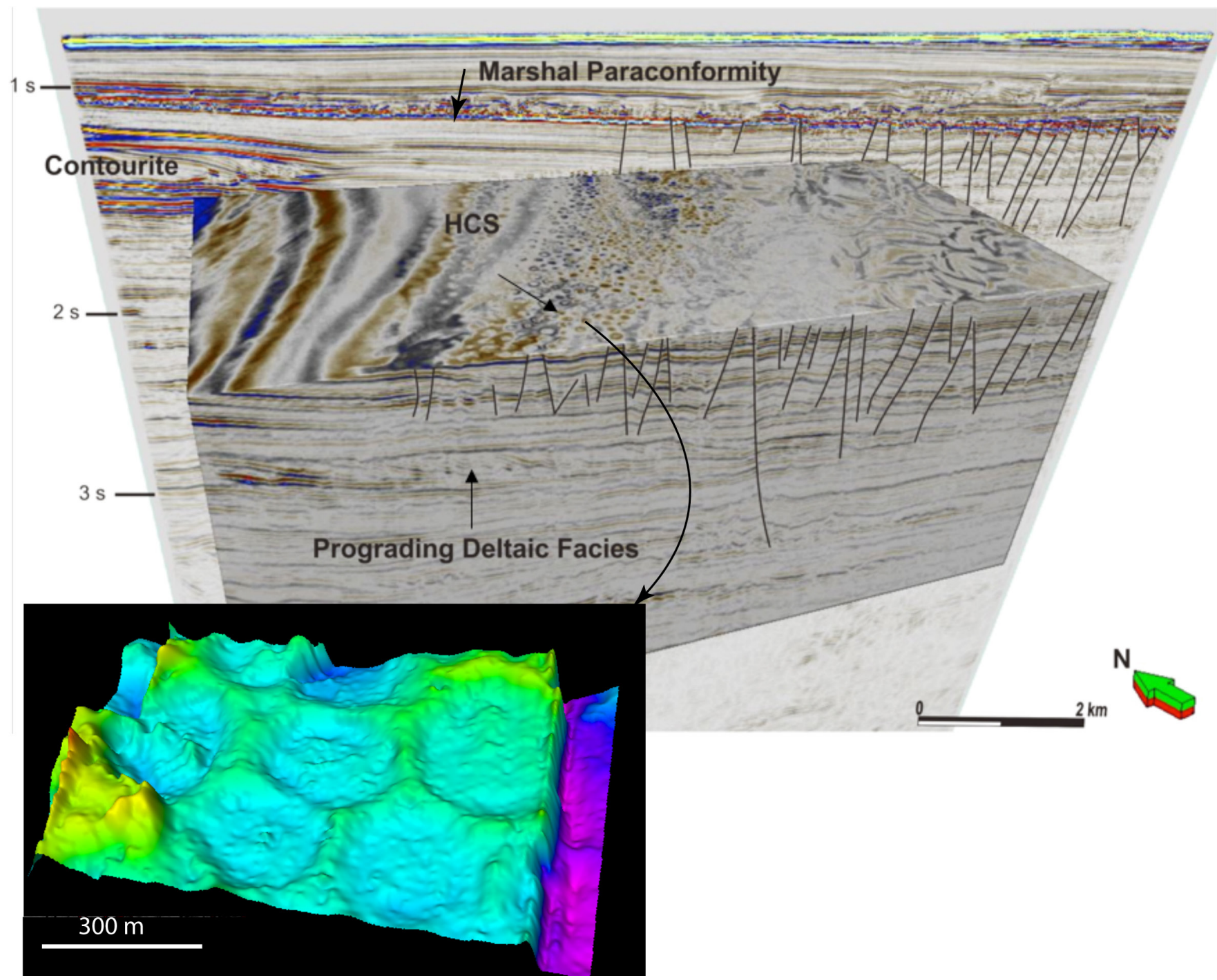

Figure 4 




Figure 5 


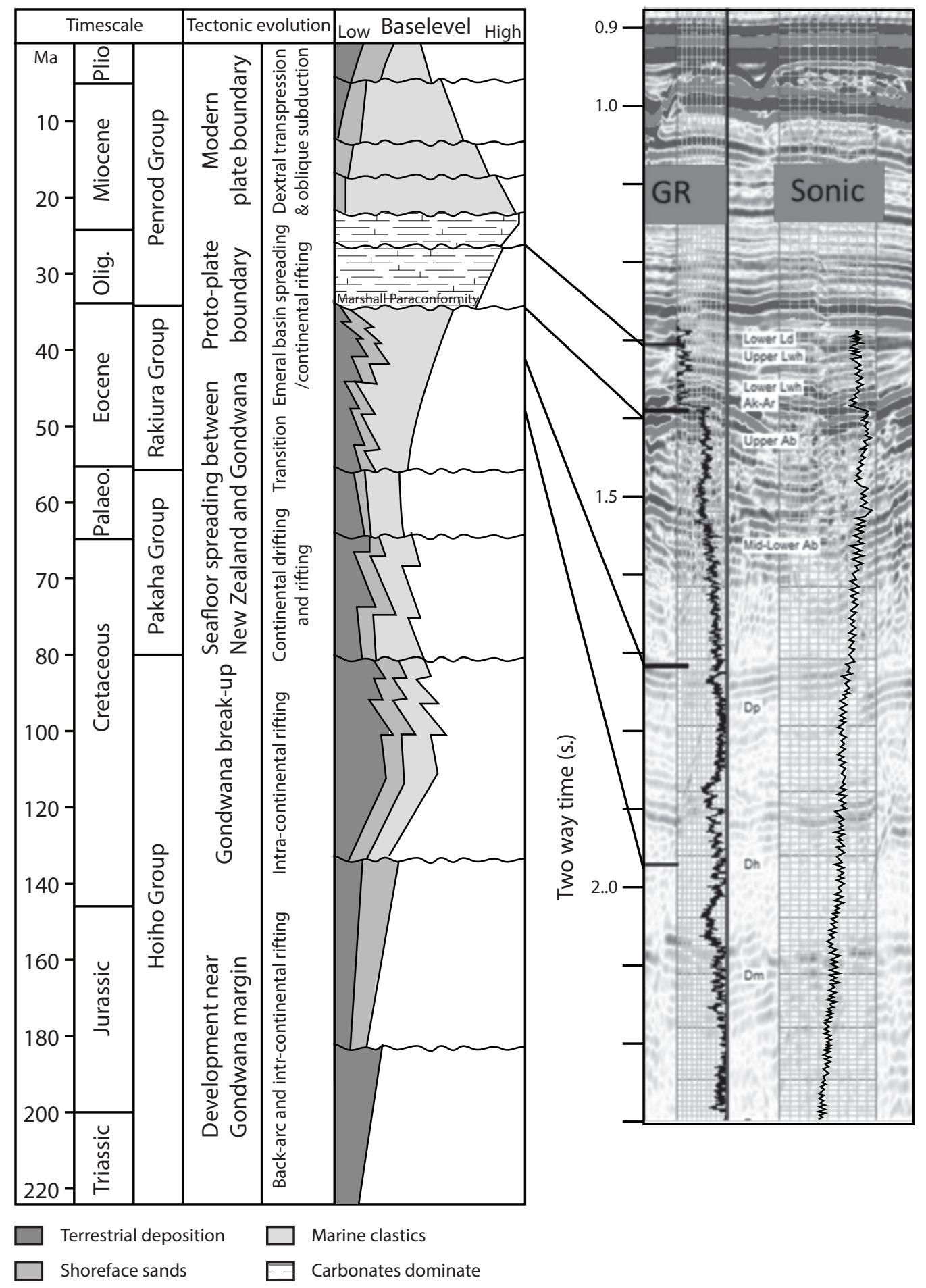

Figure 6 


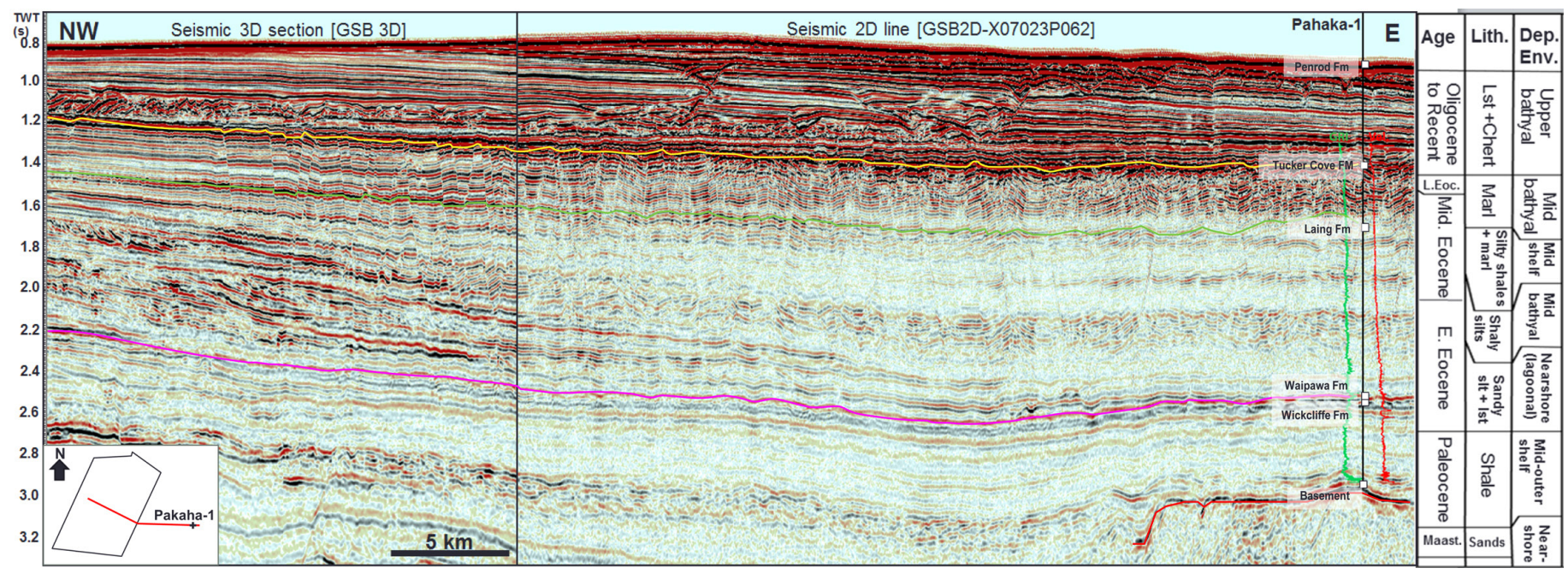

Figure 7 


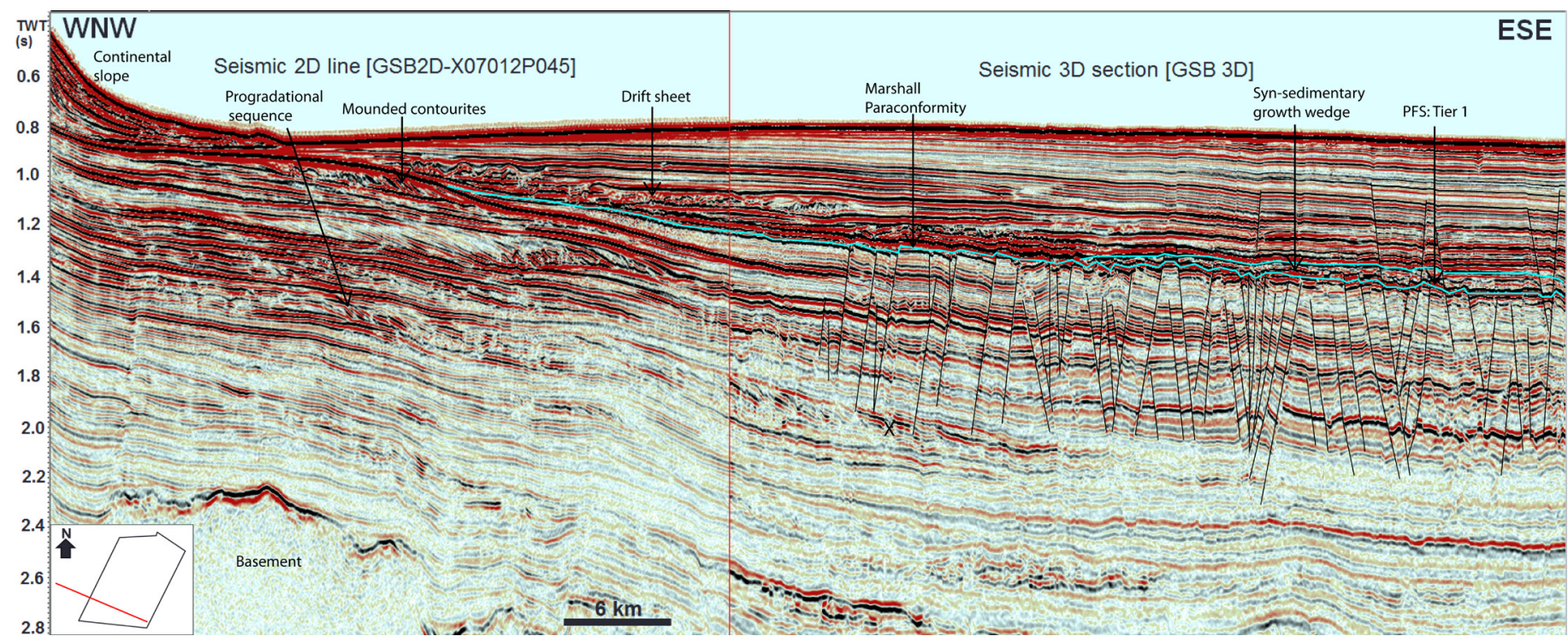

Figure 8 


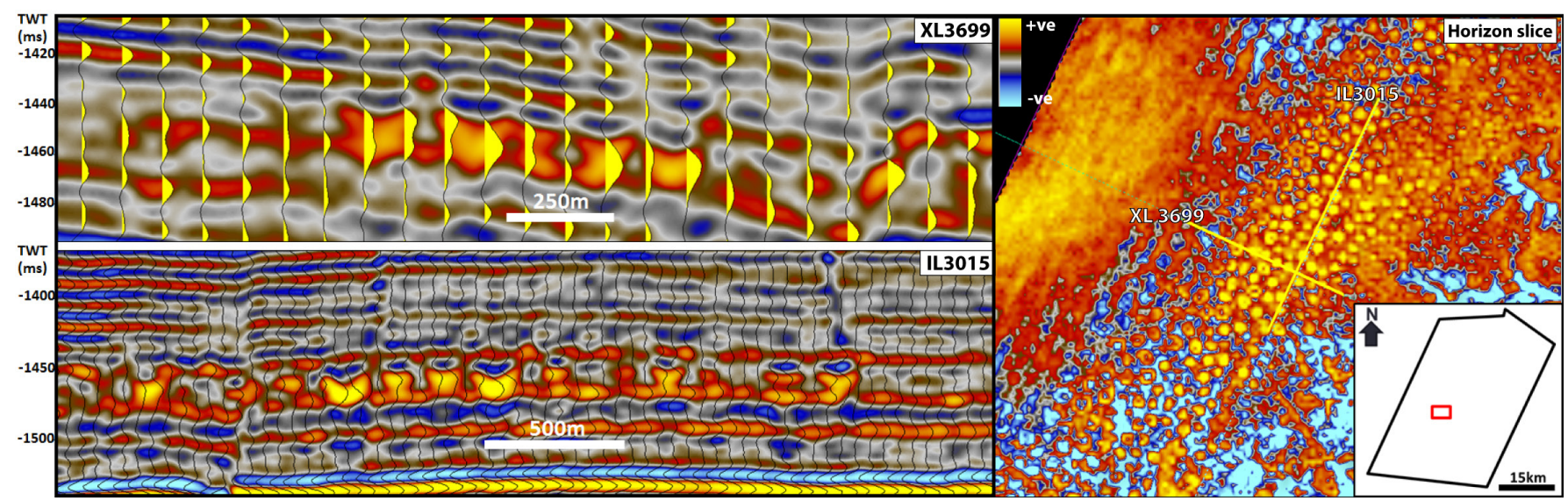

Figure 9 

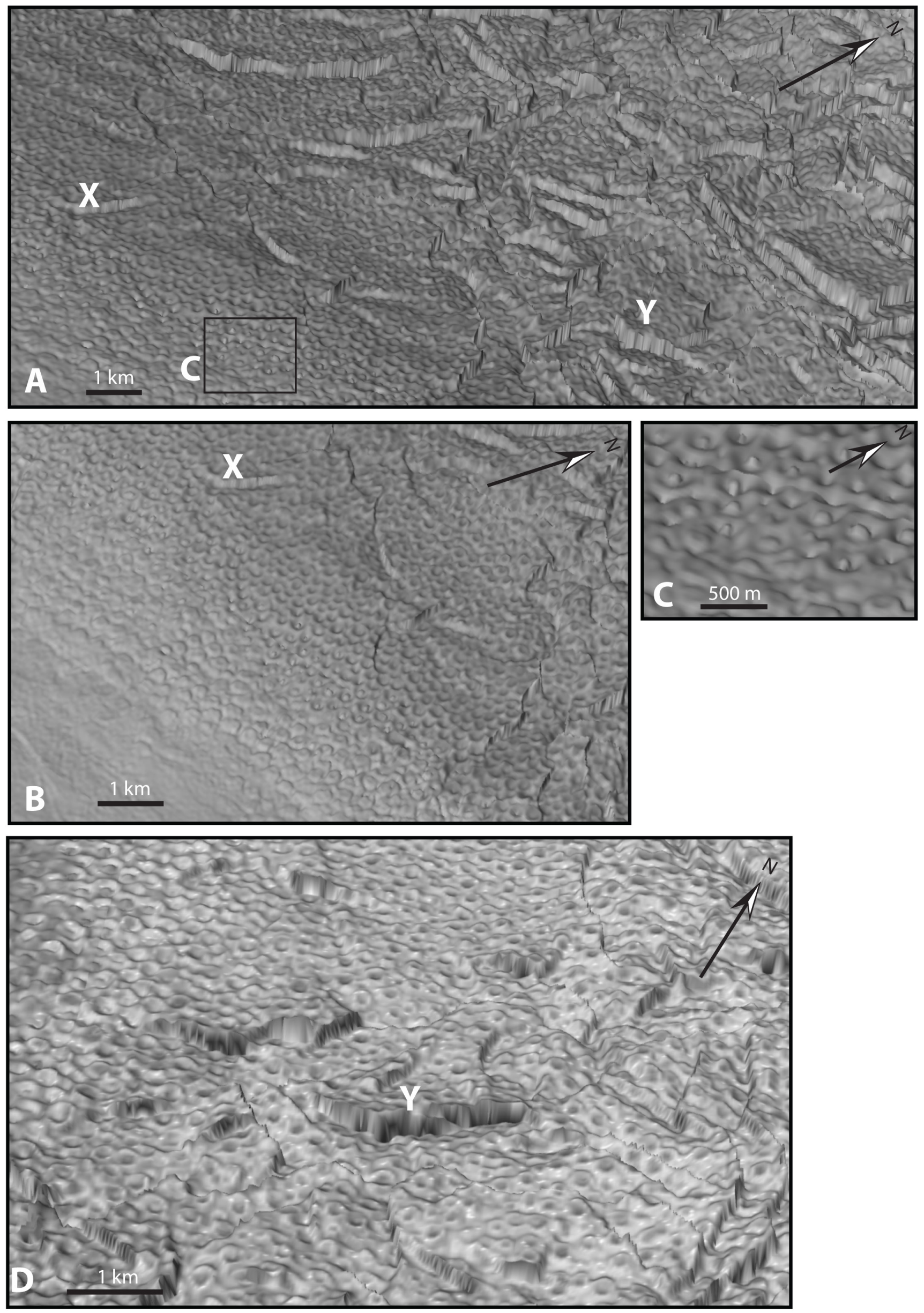

Figure 10 

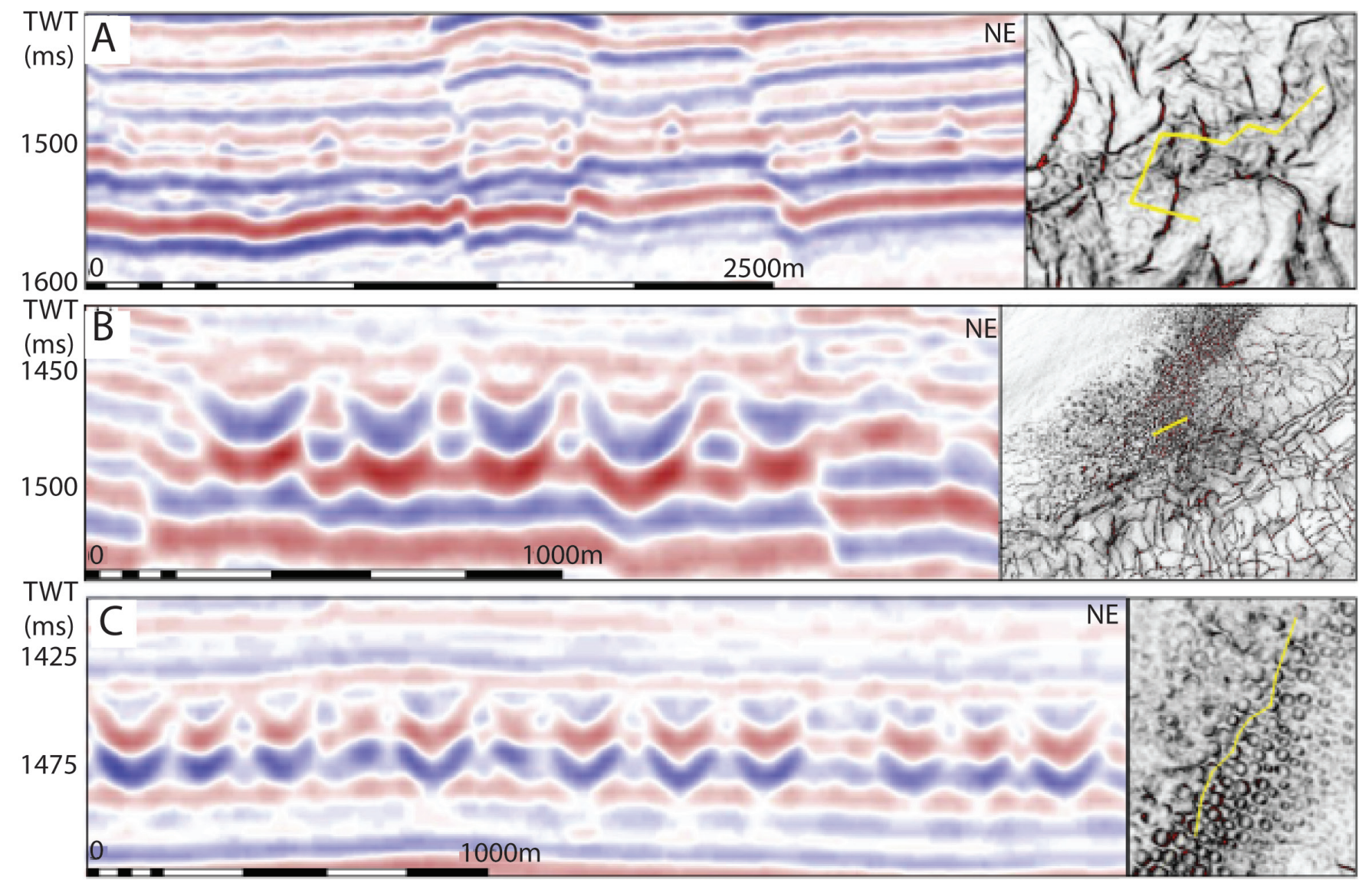

TWT
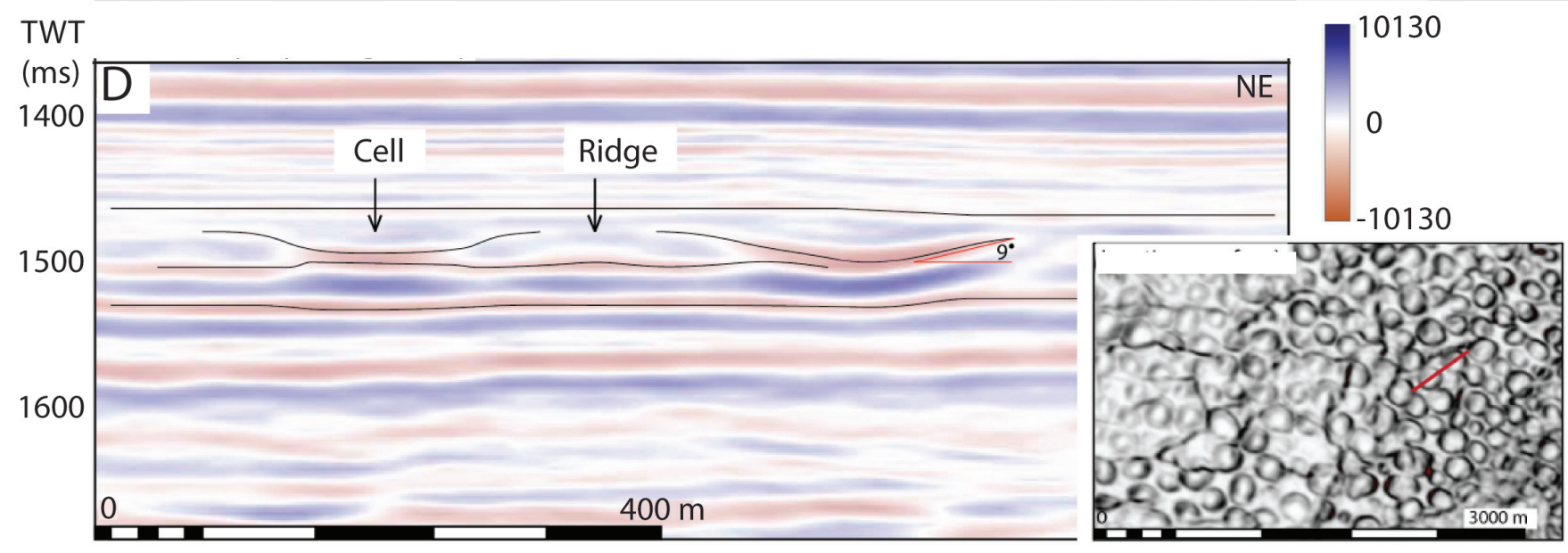

Figure 11 

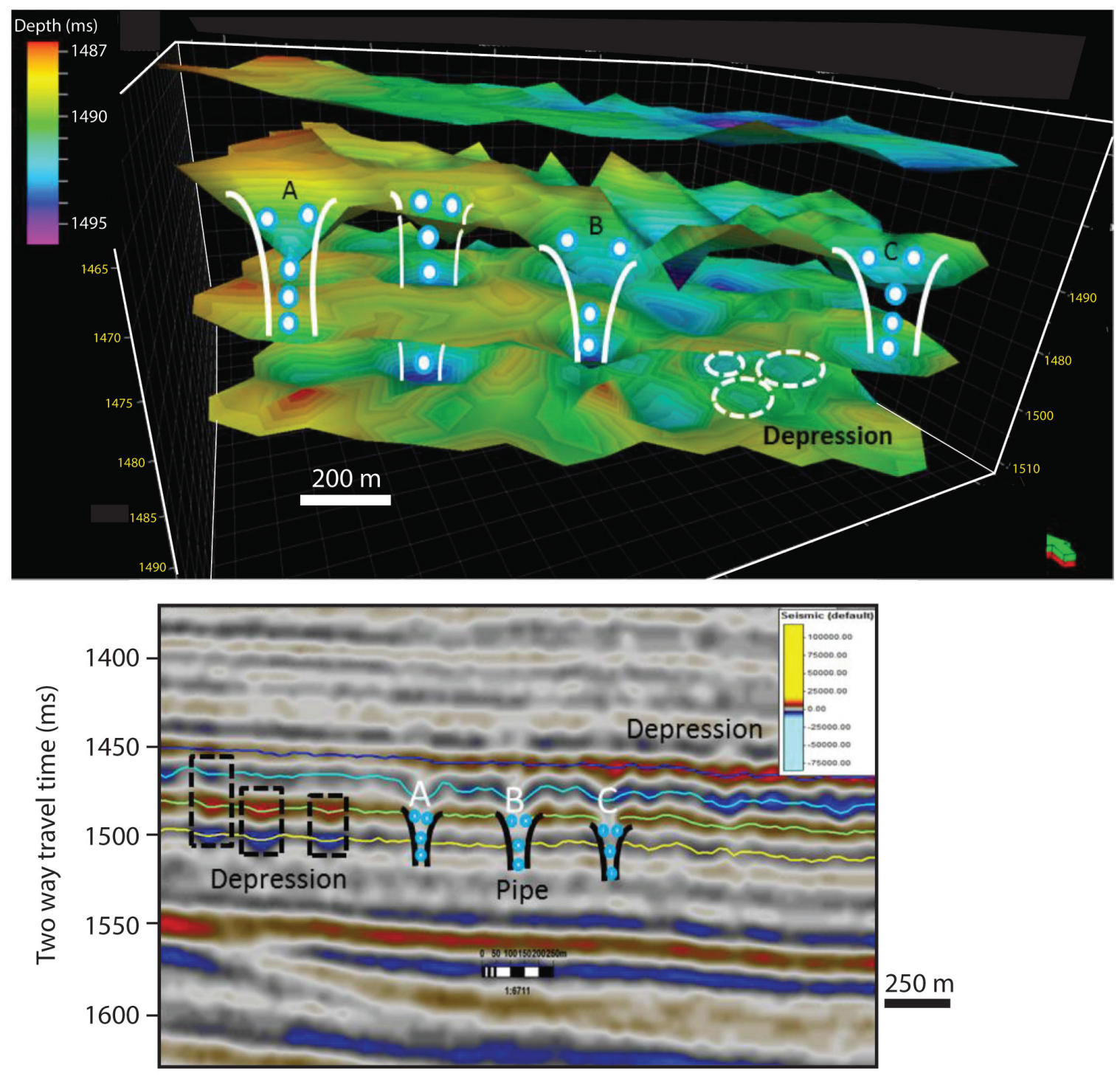

Figure 12 

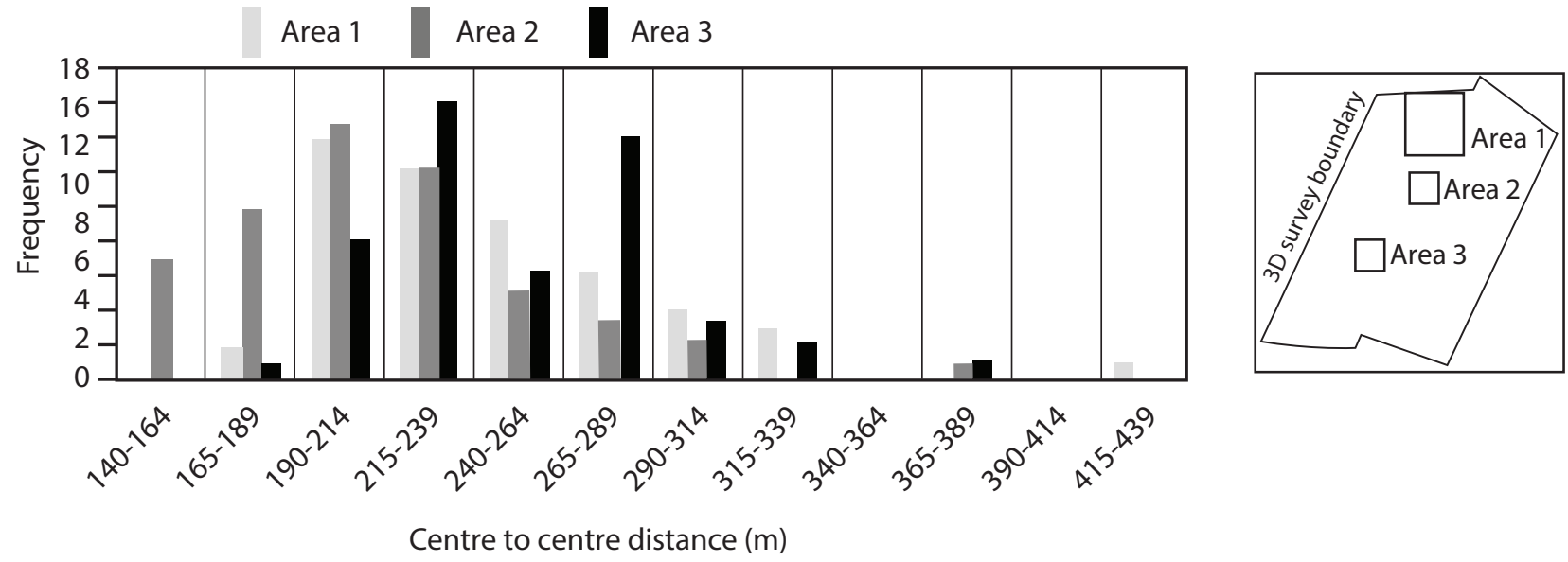

Figure 13 


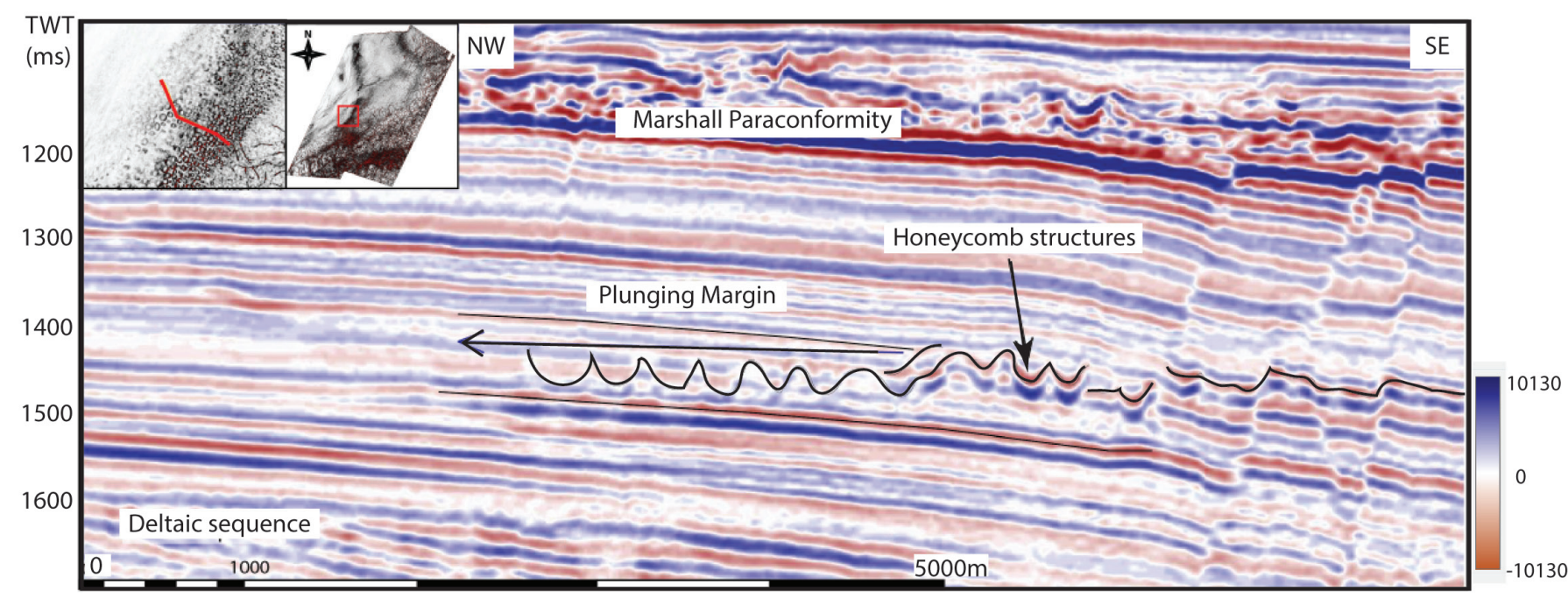

Figure 14 
